\section{KAMNIŠKA BISTRICA - GEOGRAFSKA PODOBA GORSKE DOLINE}

\section{Darko Ogrin (ur.): Kamniška Bistrica - geografska podoba gorske doline. Zbirka GeograFF 22. Znanstvena založba Filozofske fakultete in Oddelek za geografijo, I76 str. Ljubljana, 2017.}

22. številka geografske zbirke GeograFF, ki jo izdaja Oddelek za geografijo Filozofske fakultete Univerze v Ljubljani, z zgovornim naslovom »Kamniška Bistrica - geografska podoba gorske doline« napoveduje kompleksen regionalni pristop. Monografija obsega 176 strani besedila $\mathrm{z}$ vmesnimi kartografskimi, tabelaričnimi in slikovnimi prilogami. Razdeljena je na sedem poglavij in kratek, jedrnat povzetek v slovenskem in angleškem jeziku. V že dolgi vrsti znanstvenih monografij te zbirke je ta med redkimi, ki imajo pretežno regionalni pristop in prva, katere raziskovalno podlago tvori večletno delo študentov geografije v okviru terenskega dela na področju fizične geografije, nadgrajujejo pa jo študije s področja geografije turizma, varstva okolja in geografije prometa. Natek v uvodnih besedah opominja, da je bila ta Ljubljani nedvomno najbližja in najbolj dostopna alpska dolina sicer že predmet sistematičnih raziskav geologov, botanikov in geografov v sedaj že spoštljivo oddaljeni preteklosti. Ima prav, ko pravi: »napočil je čas za celovitejšo in nekoliko bolj vsestransko predstavitev«. Urednik Darko Ogrin je temu izzivu sledil in po nekajletnem raziskovalnem terenskem delu sledi uresničitev v obliki konceptualno dovršene znanstvene monografije.

Dolina Kamniške Bistrice je kljub lahki dostopnosti zadržala šarm ohranjenega visokogorskega ambienta, ki dolguje svojo turistično privlačnost izvrstni legi (in s tem seveda bližini) širše Ljubljanske urbane regije ter visokogorskemu svetu Kamniških Alp s tipičnimi, še lepo delujočimi planinami. Do nekaterih izhodišč vodijo strme gorske in gozdne ceste, privlačne za rekreacijske oblike v naravi. Za mnoge obiskovalce je razgibana dolina le rahlo razširjena cona dnevne dostopnosti: funkcijski prostor mesta v osrčju goratega sveta. Kamniška Bistrica ima vse značilnosti gorske alpske doline, makrostrukturo katere so oblikovali tektonski premiki v geološki preteklosti, brusili ledeniki, dopolnili kraški in fluvialni procesi in katere končno današnjo podobo in funkcijo ustvarja slovenska družba. Te okoliščine so si zadali avtorji podrobneje in sistematično raziskati ter prikazati, da bi ob tem uresničili primarno poslanstvo univerzitetnih profesorjev in asistentov: izobraževati, usposabljati in navsezadnje tudi vzgajati geografski podmladek na najbolj primaren način: s terenskim delom. Zapis pa ostane 
popotnica vsem drugim, ki si bodo želeli razširiti svoja vedenja o preteklih in recentnih procesih. Knjiga je pisana pregledno, plastično, dokumentirano in zanimivo; prav kakor da bi hotela informirati in vzgajati vse, ki se v gorski svet skoraj na pragu urbanega prostora zatekajo zaradi najrazličnejših vzgibov in motivov. Grafične priloge so lepo razložene in bi morale biti nazoren prikaz stanja na različnih področjih tudi bralcem, ki ožjega geografskega izrazja niso posebej vešči. Knjiga pa ni lahkotno branje, temveč najprej znanstveno besedilo, namenjeno zahtevnejši strokovni publiki.

Monografija je zasnovana enotno in sledi premišljeni predstavitveni logiki. Začenjajo jo vsebine fizičnogeografskih orisov Kamniške Bistrice: geomorfološki razvoj, pedo- in fitogeografske značilnosti, analiza topoklimatskih razmer ter hidrogeografske poteze. Avtorji so najprej podali sistematično analizo glavnih dosežkov dosedanjih raziskav, v drugem, obsežnejšem delu pa predstavili lastne raziskave, ki so jih izvajale tri generacije študentov geografije na terenskih vajah, in sicer v obliki tedenskega, zelo intenzivnega empiričnega dela. Skupaj s profesorji in asistenti (in avtorji besedil te monografije) so na najbolj izviren način usvajali metode in tehnike terenskega dela, analizirali zbrane meritve in opazovanja ter prihajali do novih strokovnih spoznanj. Krona teh prizadevanj so interpretacije s preglednimi kartografskimi prikazi. Zadnje raziskave dokazujejo intenzivno ledeniško preoblikovanje, a ne potrjujejo vseh prejšnjih domnev glede obsega ledenikov in tudi ne časa (obdobja) ledeniške kulminacije. Če je bilo za geomorfološki razvoj več zanimanja že pred desetletji, sta bila prst in rastje sedaj prvič zares sistematično proučevana. Še bolj to velja za analizo topoklimatskih značilnosti - pravzaprav posebnosti, glede na to, da so zelo podrobne raziskave odkrile sorazmerno opazne razlike med posameznimi predeli. Glavne lokalne modifikatorje topoklime so raziskovalci našli v značilnostih reliefa, konfiguraciji, ekspoziciji in drugih potezah. V hidrogeografskem orisu so pomembno težo odmerili kakovosti vode in njenim kemijskim in fizikalnim lastnostim.

Drugi vsebinski sklop sestavljajo tematike, ki opisujejo dinamična razmerja med naravo in človeško družbo, ki v ta gorski svet posega s svojimi dejavnostmi. Izhodišče tega dela knjige je poglavje o ranljivosti okolja. Pristop je sinteznega značaja, valorizacija kapacitet posameznih pokrajinskoekoloških enot ter njihovih nosilnih in regeneracijskih zmožnosti; če so presežene, sledijo degradacijski procesi. Ta razmerja so tudi lokalno zelo prepletena in lahko hitro postanejo na meji ogroženosti, čeprav je po splošnem vtisu Kamniška Bistrica dobro ohranjen in vitalen prostor. Kot takega se ga namreč marketinško prodaja: »neokrnjena narava pred vašim pragom«. O tem je sicer mogoče polemično razpravljati, a je hkrati treba priznati, da bi to le redke obiskovalce utegnilo odvrniti od namer po koriščenju visokogorske doline kot ciljne destinacije vseh rekreacije željnih obiskovalcev. Analiza turističnih tokov dokazuje raznovrstno rekreacijsko-športno motiviko, ki pa jo je mogoče dokaj prepričljivo postaviti na skupni imenovalec dostopnosti. Kamniška Bistrica je tako v funkciji elementa kakovosti bivanja prebivalcev prostora med Ljubljano in Kamnikom. Gorska dolina se s svojimi atributi naravne in tudi kulturne dediščine uvršča dejansko na rob funkcijskega prostora številnih ciljnih socialnih skupin. To in še bolj zadnje poglavje o prometnih obremenitvah implicitno usmerja kritično ost v naslednja prizadevanja o racionalni rabi prostora: osveščanju obiskovalcev o smiselnosti uvedbe do okolja obzirne rabe in tudi določenim samoomejitvam. Če kje, je na tem 
primeru mogoče prepoznati etičnost in racionalnost slogana »manj je več«. Ni problem toliko v številčnosti ter frekvenčni razporeditvi obiskovalcev, temveč v načinih in tehnikah preživljanja časa od narave odtujenega homo sapiensa, ki želi uiti mestnemu vrvežu, a prenaša svoje navade v gorske ambiente Kamniške Bistrice.

Urednik in avtorji posameznih poglavij so opravili veliko delo. Morda bi bilo smiselno izpostaviti še dve stvari: širino sedanjega človeškega vplivanja (ali če hočete: antropogenizacijo tega vsaj na prvi pogled še dokaj ohranjenega »naravnega« okolja) ter valorizacijo tega prostora tudi za druge oblike rabe. Monografija je na nek način mejnik v obliki in načinu diseminacije raziskovalnega dela s študenti. Vsega se sicer ne da, a knjiga kot da izziva k temu, da bi podobno natančno opisali tudi pretežno družbenogeografske vsebine. S tem delom so avtorji/avtorice pomembno doprinesli ne le k mnogo preciznejši predstavi o genezi in delovanju posameznih komponent te gorske doline, temveč utirajo tudi pot k njeni trajnostni rabi, razvoju in varovanju.

Jernej Zupančič 